\section{Revista de la \\ Universidad del Thulia}

Fundada en 1947 por el Dr. Jesúns Enrique Lossada

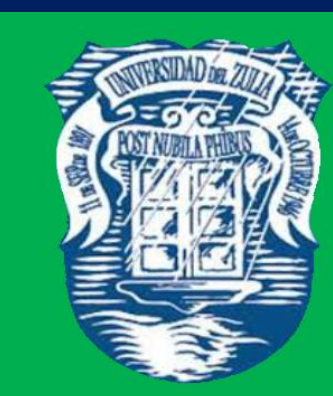

Ciencias del

Algreo

Ingemieria

y Teemología

\section{Aกัต 11 No 29}

Enero - Abril 2021

Tercera Época

Maracaibo-Venezuela 
REVISTA DE LA UNIVERSIDAD DEL ZULIA. 3épeca. Año 11 № 29, 2020

A. Chitsazan et al./// Increased efficiency of a fuel cell using h-BN electrodes... 60-78

\title{
Increased efficiency of a fuel cell using h-BN electrodes and Teflon polymer electrolyte [-C2F4-]n
}

\author{
A. Chitsazan * \\ M. Monajjemi ** \\ H. Aghaei *
}

ABSTRACT

Graphene and h-BN have been theoretically simulated for hydrogen storage and oxygen diffusion in a single fuel cell unit. Obviously, the efficiency of the PEM hydrogen fuel cells was significantly related to the amount of $\mathrm{H} 2$ concentration, the water activities in catalyst substrates and the polymer of the electrolyte membranes, the temperature and the dependence of such variables in the direction of the fuel and air currents between the anode path and the cathode. The single PEM parameter has been estimated and the results show greater fuel cell efficiency using graphene sheets and h-BN. Maximum efficiency is observed with the stoichiometry of the 5H2, $5 \mathrm{O} 2$ and 3 $\mathrm{C} 2 \mathrm{~F} 4$ molecules during adsorption. KEY WORDS: fuel cell, h-BN, electrodes, teflon, [-C2F4-] n polymer, electrolyte

*Department of Chemistry, Science and research Branch, Islamic Azad University, Tehran, Iran.

${ }^{* *}$ Department of Chemical engineering, Central Tehran Branch, Islamic Azad University, Tehran, Iran, Maj.monajjemi@iauctb.ac.ir

Recibido: 03/02/2020

Aceptado: 05/03/2020 
REVISTA DE LA UNIVERSIDAD DEL ZULIA. 3época. Año 11 N²9, 2020

A. Chitsazan et al. /// Increased efficiency of a fuel cell using h-BN electrodes... 60-78

\section{Aumento de la eficiencia de una pila de combustible mediante electrodos h-BN y electrolito de polímero de teflón $\left[-\mathrm{C}_{2} \mathrm{~F}_{4}-\right]_{\mathrm{n}}$}

RESUMEN

El grafeno y el h-BN se han simulado teóricamente para el almacenamiento de hidrógeno y la difusión de oxígeno en una sola unidad de pila de combustible. Obviamente, la eficiencia de las celdas de combustible de hidrógeno PEM se relacionó considerablemente con la cantidad de concentración de H2, las actividades del agua en sustratos catalizadores y el polímero de las membranas de electrolitos, la temperatura y la dependencia de tales variables en la dirección de las corrientes de combustible y aire entre la vía del ánodo y el cátodo. Se ha estimado el parámetro de un solo PEM y los resultados muestran una mayor eficiencia de la pila de combustible utilizando láminas de grafeno y h-BN. La máxima eficiencia se observa con la estequiometría de las moléculas de 5H2, $5 \mathrm{O} 2$ y 3 C2F4 durante la adsorción.

PALABRAS CLAVE: pila de combustible, h-BN, electrodos, teflón, [-C2F4-] n polímero, electrolito.

Introduction

Currently, fuels same as petrol, gasoline, oil, gas and coal, supply the 90\% environmental energies. The demands have been raising since the 1975s and this rise is expected for continuing due to the fast and advanced world technologies. In order to consider both efficiency and ecology, hydrogen/ oxygen fuel cells are being important key element. $\mathrm{H}_{2} / \mathrm{O}_{2}$ fuel cells are clean efficient production of energy sources in the 2lst century (Ciureanu, 2004). In $\mathrm{H}_{2} / \mathrm{O}_{2}$ fuel cells, two half-cell reactions accomplish simultaneously including, loss of electrons (an oxidation reaction) and gain of electrons (a reduction reaction) in anode and anode electrodes respectively (De Bruijn and Dam, 2008). These processes make up the formation of water from hydrogen and oxygen gases through the total redox reaction of this fuel cell (Cruz-Manzo et al., 2013).

The electrolyte in the fuel cell consists of a solid acid supported within the membrane which is saturated with $\mathrm{H}_{2} \mathrm{O}$ for any further ions transporting. Anode reaction: 
REVISTA DE LA UNIVERSIDAD DEL ZULIA. 3época. Año 11 N²9, 2020

$\mathrm{H}_{2} \rightarrow 2 \mathrm{H}^{+}+2 \mathrm{e}-$ and Cathode reaction: $1 / 2 \mathrm{O}_{2}+2 \mathrm{e}^{-}+2 \mathrm{H}^{+} \rightarrow \mathrm{H}_{2} \mathrm{O}(\mathrm{l})$ with an overall reaction: $\mathrm{H}_{2}+1 / 2 \mathrm{O}_{2} \rightarrow \mathrm{H}_{2} \mathrm{O}(2)$. In viewpoint of mechanism, at the anode, $\mathrm{H}_{2}$ first come into contact with a nickel catalyst and break apart, bonding to the nickel surface forming weak $\mathrm{H}-\mathrm{Ni}$ bonds consequently the oxidation reaction can be proceed. Each $\mathrm{H}_{2}$ releases its electron, which moves around the external circuit to the cathode which is electrical current. Then the $\mathrm{H}^{+}$bonds with $\mathrm{H}_{2} \mathrm{O}$ on the membrane surface for forming $\mathrm{H}_{3} \mathrm{O}^{+}$that moves through the membrane to the cathode electrode, leaving the nickel catalyst for the next $\mathrm{H}_{2}$. At the cathode, $\mathrm{O}_{2}$ come into contact with nickel catalyst on the electrode surface and break apart bonding to the nickel sheet forming weak O-Ni bonds, enabling the reduction reaction to proceed. $\mathrm{O}_{2}$ then leaves the nickel catalyst site, combining with two electrons that move in external circuit and two protons which have moved through the membrane for forming $\mathrm{H}_{2} \mathrm{O}$. Increasing the $\mathrm{H}_{2}$ storage is a major section for the transition more and more hydrogen molecules in a fuel cell (Larminie and Dicks, 2003).

\section{PEM fuel cells}

Obviously fuel cells as an electrochemical instrument are able to convert chemical energies straightly into direct electrical currents (DC) through a sufficient electrolyte. Therefore, it is usually far yields than combustion engines. A fuel cell needs a stable reservoir of fuels and oxidants for to keeping the electrochemical reactions, same as hydrogen and oxygen (Kazmi et al., 2009). Although Hydrogen can be used in a mixture with other gasses such as $\mathrm{N} 2 \mathrm{O}, \mathrm{N} 2, \mathrm{NO} 2, \mathrm{C} 2 \mathrm{H} 6$, the major fuel cell is electrolysis reversed consist of hydrogen and oxygen for producing electricity with high efficiency. It is notable that electrolyte has major roles which are different types this work is focused on graphene and h-BN electrodes with polymer membrane electrolyte (PEM) in low temperature. In the PEM fuels cell, the electrolytes are thin polymeric membrane including proton permeability. At low temperature around $90^{\circ} \mathrm{C}$ the presence of the catalyst such as typically nickel is needed for hydrogen oxidation reaction (HOR) and oxygen reduction reaction (ORR) on anode and cathode electrodes respectively (Scheme.1). 
REVISTA DE LA UNIVERSIDAD DEL ZULIA. 3época. Año 11 N²9, 2020 A. Chitsazan et al./// Increased efficiency of a fuel cell using h-BN electrodes... 60-78

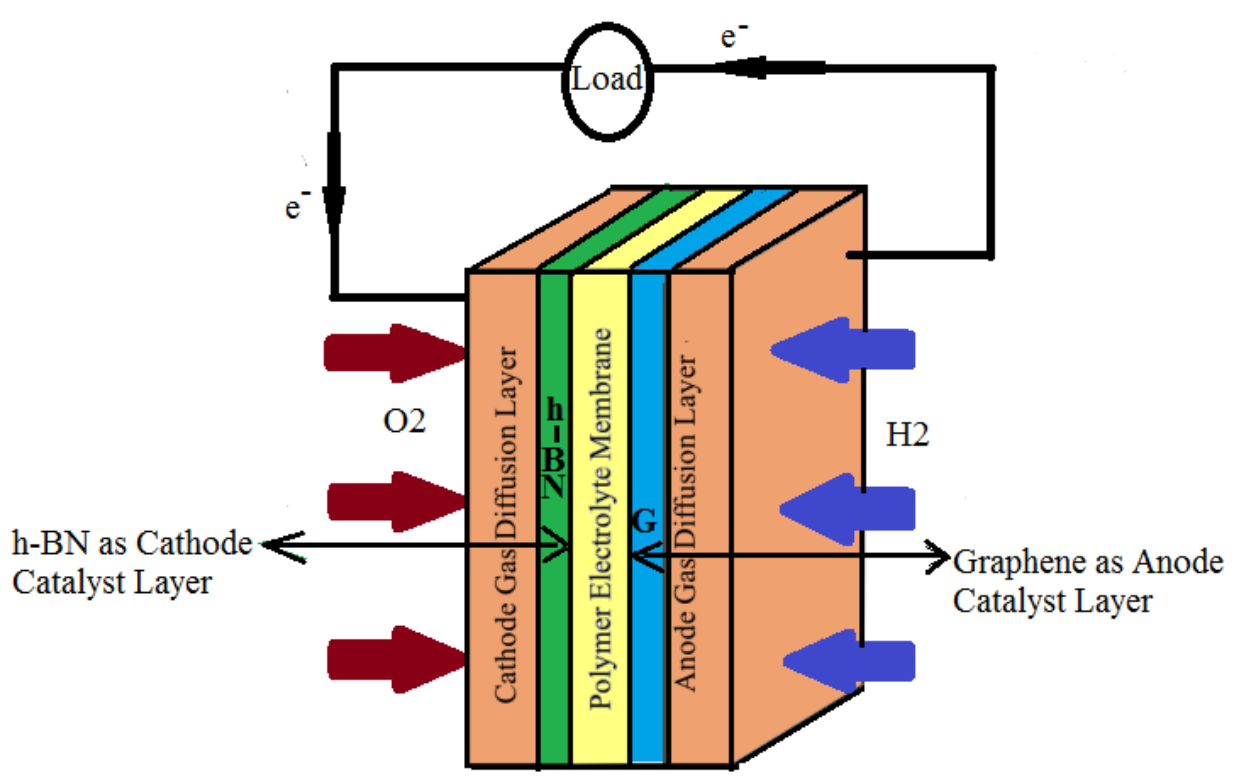

Scheme l: A schematic components of fuel cells

Cathode and anode gases diffusion layers, generally made of carbon porous including graphene layer for cathode and $\mathrm{h}-\mathrm{BN}$ for anode adjacent to catalyst, respectively which are distributed on each side of the polymer membrane. Currently, PEM fuel cell technologies have been combined to the $R \& D$ approaches in the automotive sections such as Chrysler, Toyota, Suzuki, Ford, General Motors, Volvo, Hyundai, Nissan and BMW and also as power back-up sources (Kazmi et al., 2009). The electrochemical reactions accomplish at the catalyst electrodes on both sides polymer material including oxidation and reduction (equations 1\&2). Hydrogen flows into the PEM fuel cell and diffuses through the gases diffusion layers to the catalyst layers, where catalyst particles facilitate fuel oxidation and protons trap onto water molecules to form $\mathrm{H}_{3} \mathrm{O}^{+}$that move via the membrane from the anode towards cathode. In addition two electrons from above equations (1\&2) reach to the cathode electrode over the bipolar plates and over an external circuit. It is notable that this mechanism is known as electro-osmotic drag. On the cathode electrode, oxygen gases diffuse to the catalyst layer and chemically combined with protons and electrons to form water (ORR). Obviously, the electrodes must be selected of porous materials that facilitate water moving to outside and the excess oxygen gases might 
be help for pushing water out of the cell (scheme $2 \& 3$ ). Efficiency, permanence and cost reduction effort are the most important items for PEM fuel cells that cover construction and assembly methods (Litster and McLean, 2004). There are several major items for increasing the life cycle and PEM fuel cells efficiency which are thermal management, water management, new catalysts, and novel material of membranes and also quality of electrodes. Operating conditions and operating strategies play an important role in a fuel cell lifecycle. Bad distribution of fuel cell reactants can appear in the presence of high cell currents, liquid water, fuel impurities, and different flows of fuel due to the sudden changes in the power demand and conditions between cell inlet and outlet.

In other hand, fuel starvation can cause severe degradation during of gross fuel starvation that cell voltages can become negative (as the anode) and the carbon is consumed given the lack of fuel, consequently anodic current will be provided by carbon corrosion to form carbon dioxide (Schmittinger and Vahidi, 2008).

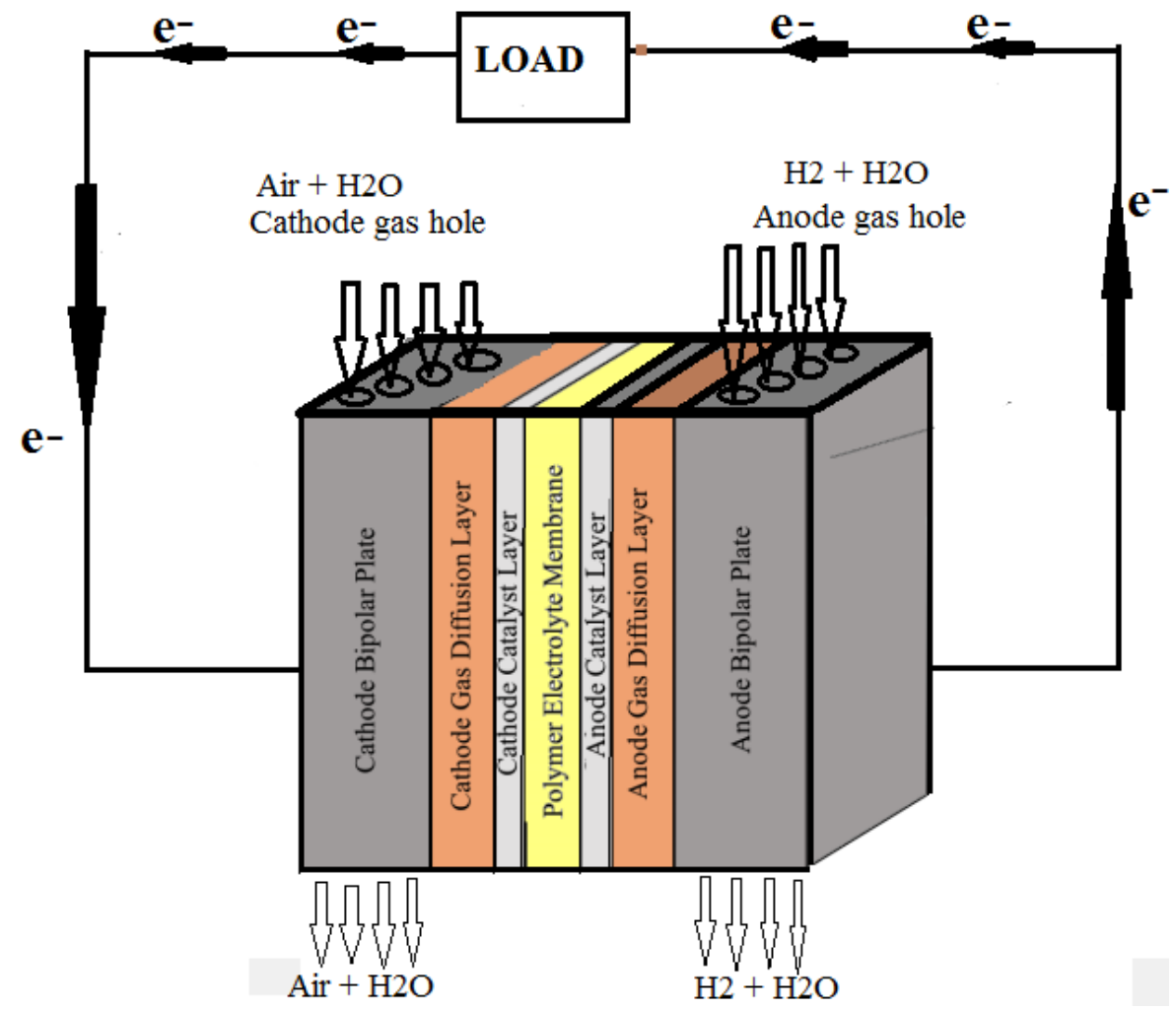

Scheme 2: one unit of PEM fuel cell structure

In addition, oxygen starvation can result in generation of hydrogen in the cathode or oxygen in the anode similarly during oxygen starvation the reaction at the cathode will 
REVISTA DE LA UNIVERSIDAD DEL ZULIA. 3época. Año 11 N²9, 2020 A. Chitsazan et al./// Increased efficiency of a fuel cell using h-BN electrodes... 60-78

produce hydrogen. For avoiding these problems the suitable monitoring controlling sensors and indicators are needed (Borup, 2007). Several studies have shown that thermal management is important, higher temperature might be producing the radicals consequently the electrochemical surface area (ECSA) decrease the life time. There are various cooling methods for PEM fuel cells which one important has been investigated by Fly among Liquid-cooled air-cooled and evaporative-cooled fuel cells. Water management is essential and most important issues in PEM fuel cell technologies which dependent to adequate membrane hydration and avoidance of water flooding in the catalyst layers. It is important to keep the membrane and the catalyst layer humidified for high proton conductivity. In the presence of $\mathrm{H} 2 \mathrm{O}$, the protons produce $\mathrm{H} 3 \mathrm{O}+$ on the boundaries of the catalyst layer and the membrane which prevent of the proper activity of the protons from the anode catalyst layer to the cathode catalyst layer in aqueous phase. Therefore, tuning humidification of the membranes is also a basic way of cell performance while accumulation of too much water also impacts performance and lifetime (Zawodzinski et al., 1993).

Excess water blockages can instantly lead to reactant starvation and water flooding is an important limiting factor of PEM fuel cell efficiency and life time. Flooding appears in both cathode and anode electrodes with three mechanisms as; (a) Water generated in the cathode side of the membrane by the electrochemical reaction (ORR), (b) electroosmotic drag and (c) over-humidified reactant gases. Anode flooding is much longer than the cathode flooding (Mollaamin et al., 2019). Although flooding in the cathode is much common compared to anode, flooding on the anode side of the membrane can also have serious consequences on the operation, performance and degradation and due to low fuel flow rates, removing $\mathrm{H} 2 \mathrm{O}$ from anode is much more difficult compared to cathode. 
REVISTA DE LA UNIVERSIDAD DEL ZULIA. 3épeca. Año 11 № 29, 2020

A. Chitsazan et al./// Increased efficiency of a fuel cell using h-BN electrodes... 60-78

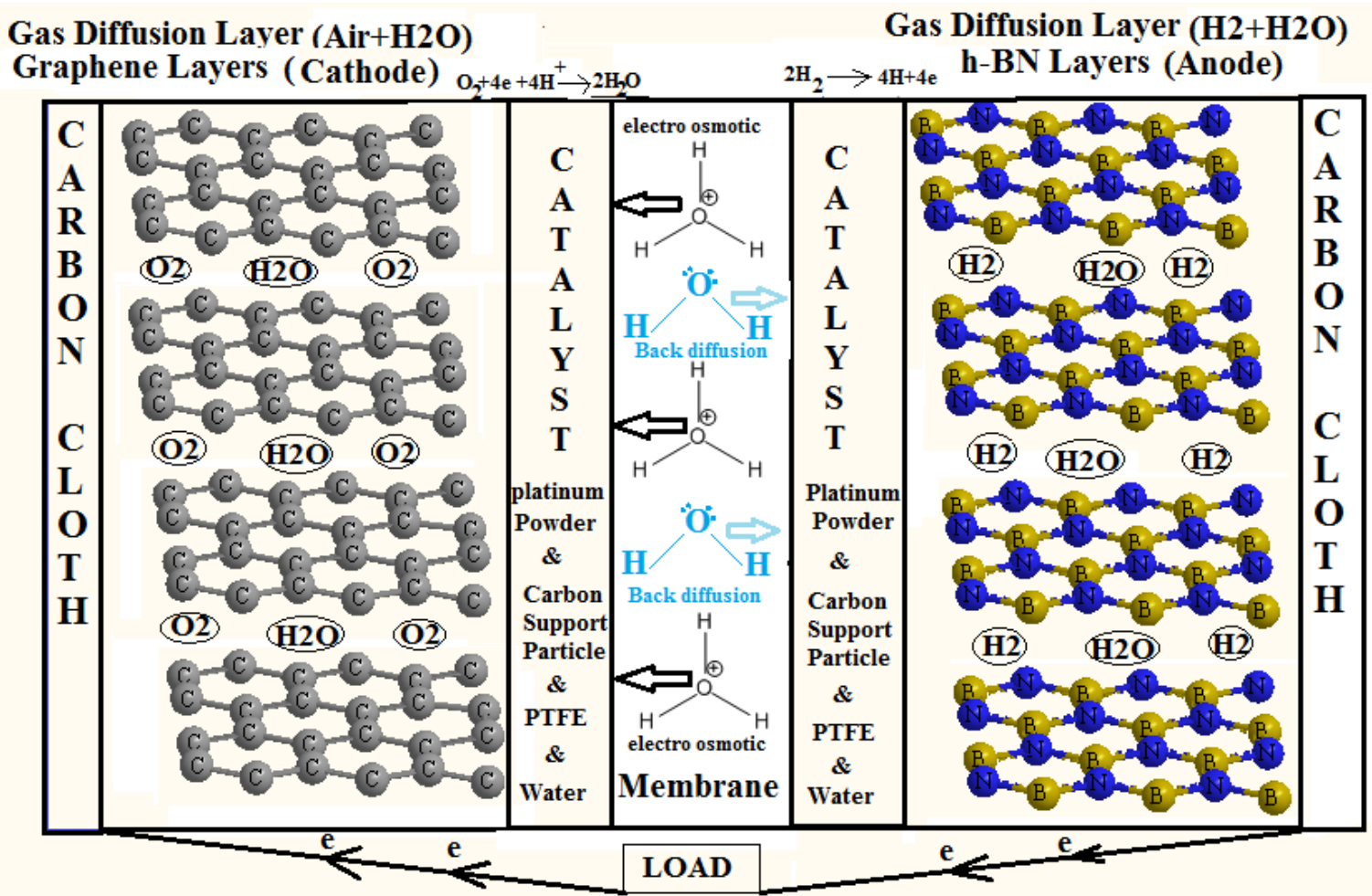

Scheme 3: Schematic model of all layers including $\mathrm{h}-\mathrm{BN}$ and graphene layers and their activities in a whole unit of the fuel cell

Pasaogullari has reported, anode flooding is most probable for happening at low current, low reactant flow rates and low temperatures due to the lower electro-osmotic forces (Pasaogullari and Wang, 2005). In other words proton flux is large in the anode electrode; therefore a strong electro-osmotic force pulls the $\mathrm{H} 2 \mathrm{O}$ from anode to cathode (due to the low water content). In contrast to the inlet of the anode side, at the exit current density is lower and $\mathrm{H}_{2}$ concentration has decreased, so, the partial pressure of water is high and closer to total anode pressure (Futerko and Hsing, 2000). Several researchers (Wang et al., 2001) have assessment various tactics and technics for water managing (Dutta et al., 2000). He et al. associated partial pressure straightly to the flooding level and considered it to be a suitable indicator for efficiency. They planned a tool for monitoring the flooding measure in PEM fuel cell with inters digitized flow field. Diperno and coworkers (Bosco and Fronk, 2000) record a USA patent for a simple way which monitors the pressure drop across the flow field to detect flooding in PEM fuel cells. Problem of 
REVISTA DE LA UNIVERSIDAD DEL ZULIA. $3^{\text {a }}$ época. Año 11 N²9, 2020 A. Chitsazan et al./// Increased efficiency of a fuel cell using h-BN electrodes... 60-78

membrane dehydration is related to drying out in anode which causes a protonic resistance and consequently collapse in cell voltage. Therefore in dried situation radicals will produce and increased, to enhanced membrane degradation (Le et al., 2006). Anode dehydration is might be serious both at the inlet of the cell and at the outlet trajectory. In addition due to dehydrating conditions, the membrane leads to lower diffusion. One of the main reasons for dehydration is the strong electro-osmotic forces in the condition of high current densities where water replenishment by reactant humidification or back-diffusion is not quick enough to cope with the lack of water (Ciureanu, 2004).

\section{Theoretical Background}

The enthalpy of hydrogen combustion reaction or hydrogen heating amount for one mole of hydrogen can be calculated via $\Delta H=\Delta H_{f}^{0}(H 2 O)-\Delta H_{f}^{0}(H 2)-\frac{1}{2} \Delta H_{f}^{0}(O 2)=$ $-286.31 \mathrm{Kj} / \mathrm{mol}$. Hydrogen heating amounts are used as a measure of energies input for the fuel cells and this is the maximum value of thermal energy which can be extracted from hydrogen. In addition Gibbs free energy is given by the following equation: $\Delta G=\Delta H$ $-\mathrm{T} \Delta \mathrm{S}$. which the difference between entropies of products and reactants can be calculated as $\Delta S=\Delta S_{f}^{0}(H 2 O)-\Delta S_{f}^{0}(H 2)-\frac{1}{2} \Delta S_{f}^{0}(O 2)$. The maximum electrical work is: $W_{\max }=$ $-n($ emf $) F=-\Delta G$ where $F$ is Faraday's constant and "emf" is the ideal electro motor force or potential of the cell. Therefore the theoretical hydrogen/oxygen fuel cell potential or maximum voltage of fuel cells is: emf $=E=\frac{-\Delta G}{n F}=\frac{237.342 \mathrm{~J} \mathrm{~mol}^{-1}}{2 * 98486.5 \mathrm{Coulmb}^{2}}=1.231 \mathrm{Volt}^{\text {. The }}$ thermal efficiency is defined based on amount of useful energy released when a fuel is reacted with an oxidant $(\Delta G)$, relative to the change in stored chemical energy $(\Delta H)$ therefore The maximum theoretical yields in a fuel cell is $\eta=\frac{\Delta G}{\Delta H}=\frac{237.342}{-286.31}=\% 82.9$ [5]. Based on Nernst equation a function of temperature and pressure can be applied for any fuel cells as; emf $=E_{(T, P)}=-\left(\frac{\Delta H}{n F}-\frac{T \Delta s}{n F}\right)+\frac{R T}{n F} L n\left[\frac{P_{\mathrm{H}_{2}} P_{2}^{0.5}}{P_{\mathrm{H} 2 O}}\right]$, (1) based on this equation, in an open circuit with reactant gases the actual cell potential is decreased (usually less than IV) and it is called open circuit voltage (OCV). This decreasing of actual cell 
REVISTA DE LA UNIVERSIDAD DEL ZULIA. 3época. Año 11 N²9, 2020 A. Chitsazan et al. /// Increased efficiency of a fuel cell using h-BN electrodes... 60-78

potential is due to irreversible losses and hydrogen crossover losses which often called polarization, over potential, or over voltage including activation polarization, ohmic polarization and concentration polarization. Activation polarization is associated with sluggish electrode kinetics which happens at both anode and cathode which can be expressed with Tafel equation: $\Delta V_{a c t}=\frac{R T}{\alpha F} \ln \frac{i}{i_{0}}$ (2) where $\alpha$ is the electron transfer coefficient of the reaction at the electrodes and $\mathrm{i} 0$ is the exchange current density.

The ohmic polarization appears due to resistance against the flow of protons in the electrolyte and also resistance to the flow of electrons through the electrode materials as the equation $\Delta V_{\text {ohm }}=i \Omega$ where $\mathrm{i}$ is the current flowing through the cell and $\Omega$ is the total cell resistances consist of electronic, ionic and contact resistance. Concentration polarization is due to loss of potential because of inability of the surrounding material for maintaining the initial concentration of the bulk fluid, thus, a concentration gradient is formed. $\Delta V_{\text {conc }}=\frac{R T}{n F} \ln \left[\frac{i_{L}}{i_{L}-i}\right]$, That $i_{L}$ is the limiting current. The actual cell voltage can be written as: $V_{\text {cell }}=E(T, P)-\left(\Delta V_{\text {act }}+\Delta V_{\text {conc }}\right)_{a}-\left(\Delta V_{\text {act }}+\Delta V_{\text {conc }}\right)_{c}-\Delta V_{\text {ohm }}$ (3) by replacing the above equations in this equation the fuel cell polarization curve is: $V_{\text {cell }}=E(T, P)-\frac{R T}{\alpha_{c} F} \ln \frac{i}{i_{0, c}}-\frac{R T}{\alpha_{a} F} \ln \frac{i}{i_{0, a}}-\frac{R T}{n F} \ln \left[\frac{i_{L, a}}{i_{L, a}-i}\right]-\frac{R T}{n F} \ln \left[\frac{i_{L, C}}{i_{L, C}-i}\right]-i \Omega$. (4) Due to the activation energy barriers the polarization terms voltage collapse very fast and in the ohmic term polarization voltage falls slower due to the membrane and electrode ohmic resistance.

\subsection{Modelling and simulation}

The details mechanism of the PEM fuel cells are very complex due to the different and tightly phenomenon which occur within a cell-fluid-dynamic, migration, electro chemical reaction, diffusions, water transports inside polymer membrane involving both electro-osmotic drag and back diffusion, proton transports via proton-conductivities of the polymer membranes, electron conduction via electrically conductivities of the cell components, heat transfer involving both conduction via solids components of the cells 
REVISTA DE LA UNIVERSIDAD DEL ZULIA. 3época. Año 11 N²9, 2020 A. Chitsazan et al./// Increased efficiency of a fuel cell using h-BN electrodes... 60-78

and convection of reactant gases and cooling medium, water transports both evaporation and liquids via porous catalyst layer, gas diffusion layer, and phase Changes (scheme 4).

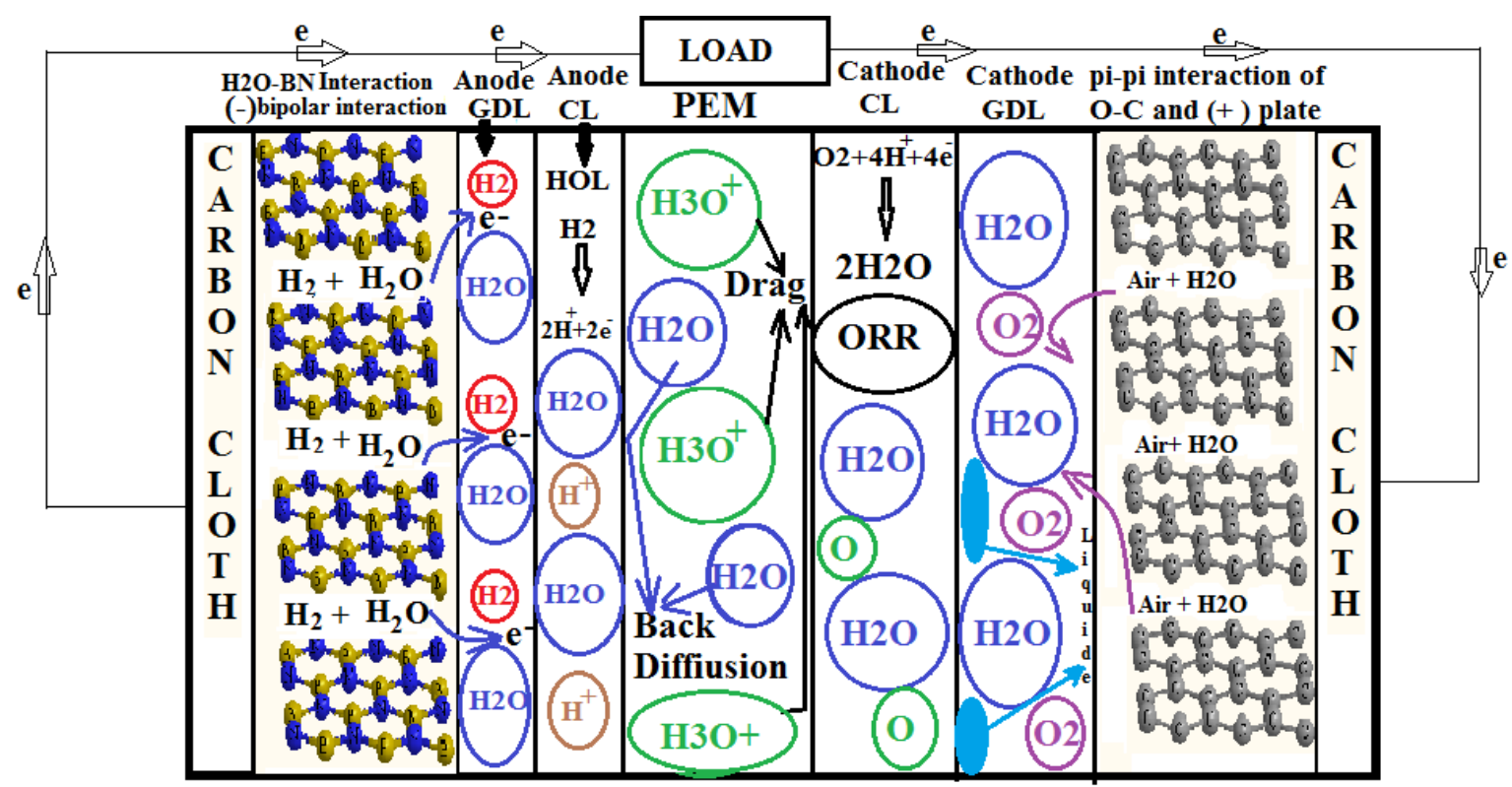

Scheme 4.

Processing and operating of a PEM fuel including $\mathrm{h}-\mathrm{BN}$ and cell Modelling is needed for describing the basically phenomenon to evaluate the cells steady-state and dynamic behavior. However, the complex mechanism inside the fuel cell causes challenging in some models involving reactants, cooling, and humidification and conditioning systems. Models are able to predict fuel cell efficiency under different operating situations and optimization and designing of control systems (Rowe and Li, 2001). In past decades, several of PEM fuel cell models are defined to the purpose of gas channel, gas diffusion layers, catalyst layers and polymer membrane of electrolyte (Siegel, 2008). Models can also be categorized based on their dimension, single, double or triple which can be considered either isothermal or non-isothermal (Yao et al., 2004). Single cell model explain the electrochemical and transporting processes in the fuel cell component including pressure drop, flow distribution, and temperature profile in the gas channel (Pukrushpan et al., 2004). This simulation, quantitatively explain interaction between physical and electrochemical phenomenon which can also be divided into two sections, 
REVISTA DE LA UNIVERSIDAD DEL ZULIA. 3época. Año 11 N²9, 2020 A. Chitsazan et al./// Increased efficiency of a fuel cell using h-BN electrodes... 60-78

first an empirical simulation for prediction how the fuel cell voltages change with the current densities with polarization curves and second principle simulation is built- up from ordinary differential equations or solving partial differential equations (PDEs) including distributed parameter, Stefan-Maxwell convection and diffusion account for species conservation. Based on Darcy's law, the principle of mass conservation is applied to simulate reactant concentration (Gurau, 1998).

Recently, in advance simulation, two-dimensional and three dimensional simulations have been developed. The two-dimensional simulation can be separated into two classes, first one explain the plane perpendicular to the flow channels and second describes the direction along the flow channel (Karimi, 2011) An extended simulation of 3-dimensional, 2-phase, non-isothermal unit cell systems were investigated by Tao for performing parameters sensitivities examination. Generally, simulated systems are lumped data of parameters for evaluating fuel cell efficiency under various operating situations for any controlling as a function of time through solving differential equations (ODEs) (Tao et al., 2006). Pukrushpan investigated a system including fuel cell stack, hydrogen supply, air supply, cooling and the humidification systems with a constant temperature due to the dynamics variables (Pukrushpan et al., 2004).

\section{Computational details}

Calculations were accomplished via GAMESS-US package (Schmidt et al., 2004). DFT methods such as m062x, m06-L, and m06 for the non-bonded interaction of fuel cell layers including G/h-BN// h-BN / G have been used. The m062x, m06- $\mathrm{L}$ and m06-HF are new DFT functional with a good correspondence in non-bonded calculations which are useful for estimating the energies of distance between layers in the fuel cells simulation (Zhao and Truhlar, 2008). The double $\zeta$-basis set with polarization orbitals (DZP) were applied for calculated for inputs and outputs parameters for the simulation fuel cells. Graphene is known to relax in 2-D honeycomb structures and the h-BN also will be assumed to have a similar structure. A monolayer of graphene containing 76 atoms with zigzag edges was optimized and allowed to relax to its minimum energies structures. The 
REVISTA DE LA UNIVERSIDAD DEL ZULIA. 3época. Año 11 N²9, 2020 A. Chitsazan et al./// Increased efficiency of a fuel cell using h-BN electrodes... 60-78

edges were saturated with the hydrogen atoms for neutralizing the valance of terminal carbon, reducing the edge effect after relaxation. The C-C-C angle was calculated to be around 120.0 and the $\mathrm{C}-\mathrm{C}$ and $\mathrm{C}-\mathrm{H}$ bound lengths are about 1.422 and 1.086, respectively which are corresponds to reported paper (Zhao and Truhlar, 2008). Generalized gradient approximation (GGA) is adopted. In our model, the electrodes have been doped by various percentages of boron atoms which are likely to be adjusted by the surrounding host $\mathrm{C}$ atoms. Therefore, when the graphene sheet is doped with one boron atom, the boron atom also undergoes the $\mathrm{sp}^{2}$ hybridization (Perdew and Burke, 1996). Using the computational procedure as stated above, the electronic properties, especially the band structure can be calculated. Via doping boron atoms in graphene, Fermi levels shifts significantly below the Dirac point resulting in a p-type doping. This would break the symmetry of graphene into two graphene sub-lattices due to presence of the B atoms which would eventually lead towards a change of the behavior of graphene from semimetal to conductor which significantly is useful for fuel cells. The charge transfer and electrostatic potentialderived charge were also calculated using the Merz-Kollman-Singh (Besler et al., 1990; Chirlian and Francl, 1987). We have also extracted the charge density profiles from firstprinciples calculation through an averaging process described.

\section{Conclusion}

For the model of these fuel cells, the adsorption energies of various number of $\mathrm{H}_{2}$, $\mathrm{O}_{2}$ over the surfaces of graphene and $\mathrm{h}-\mathrm{BN}$ sheets have been calculated both in the anode and cathode plates (Figs.l \& 2). 
REVISTA DE LA UNIVERSIDAD DEL ZULIA. 3época. Año $11 \mathrm{~N}^{\circ}$ 29, 2020 A. Chitsazan et al./// Increased efficiency of a fuel cell using h-BN electrodes... 60-78

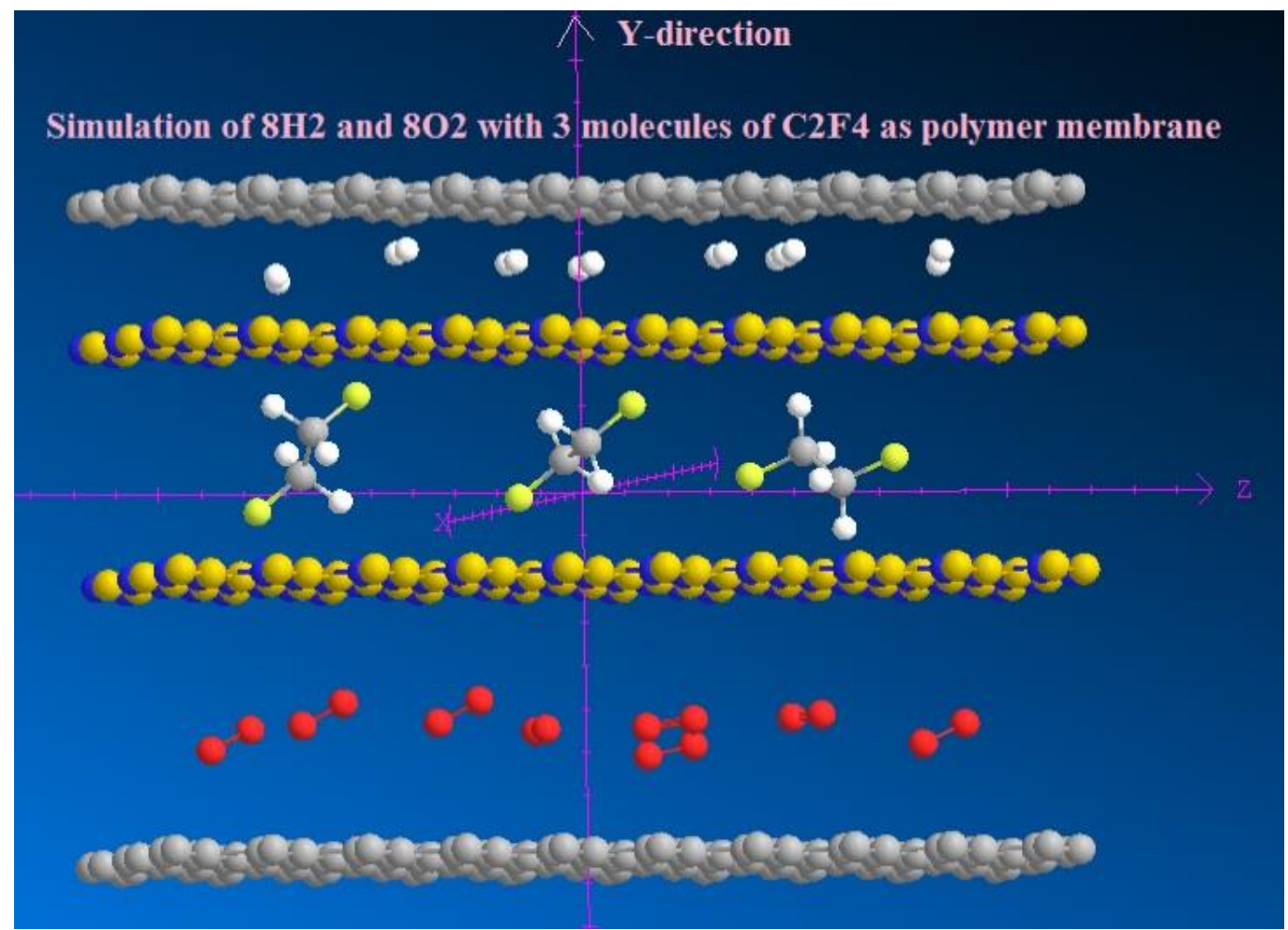

Fig. l: Adsorption of $8 \mathrm{H}_{2}, 8 \mathrm{O}_{2}$ and $3 \mathrm{C}_{2} \mathrm{~F}_{4}$ as polymer membrane for a unit cell.

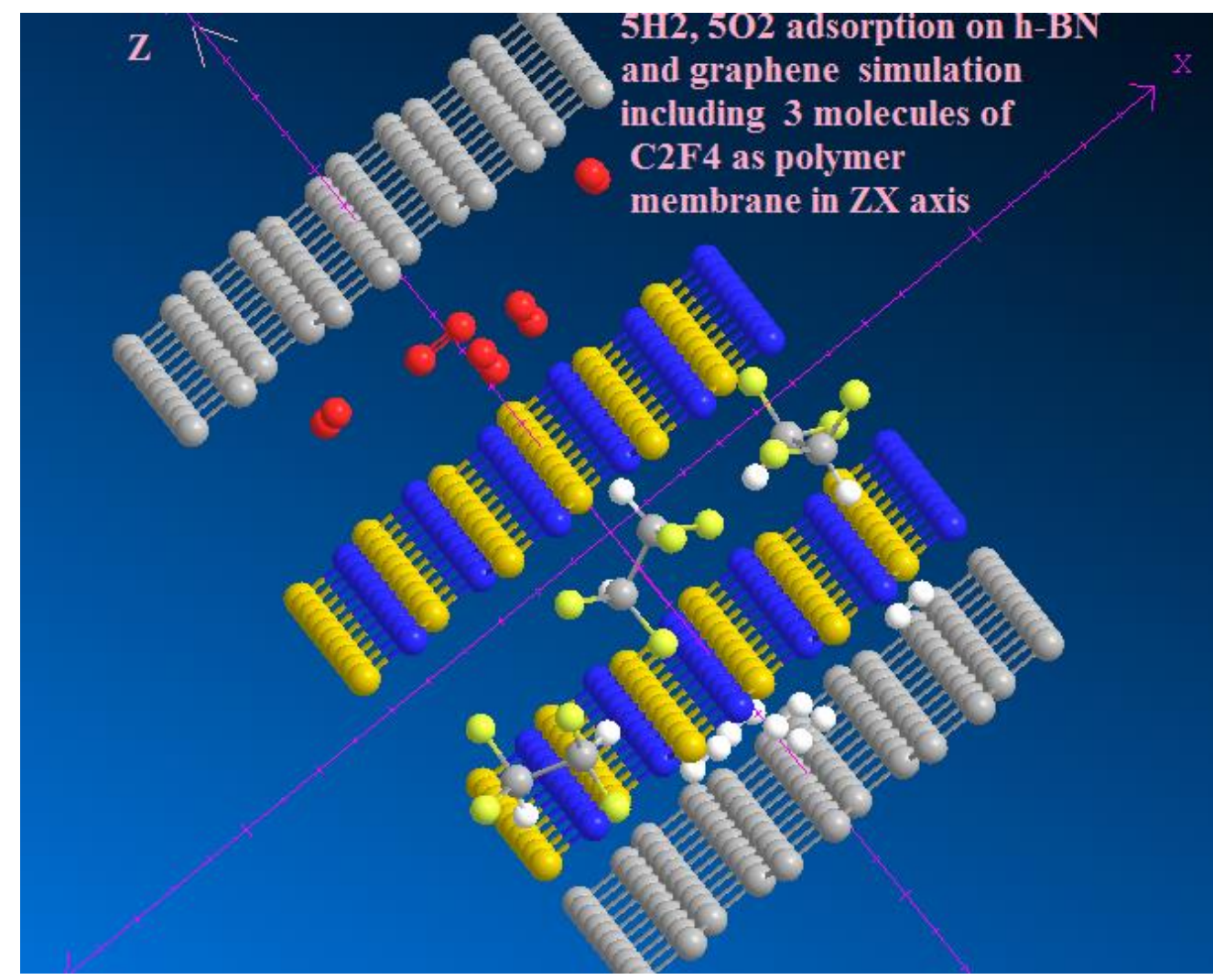

Fig. 2: Adsorption of $5 \mathrm{H}_{2}, 5 \mathrm{O}_{2}$ and $3 \mathrm{C}_{2} \mathrm{~F}_{4}$ 
REVISTA DE LA UNIVERSIDAD DEL ZULIA. 3época. Año 11 N²9, 2020 A. Chitsazan et al./// Increased efficiency of a fuel cell using h-BN electrodes... 60-78

Initially, we assume that the adsorption is Langmuir uniformly both on graphene and $\mathrm{h}$-BN sheet. The adsorption energies can be calculated as follows: $E_{\text {adsorb }}^{H 2}=$ $\frac{1}{n}\left(E_{\text {total }}-E_{h-B N}-n E_{H_{2}}\right)+E_{B S S E}$ Where BSSE is basis set error position. We obtain the stable situation after the modified system is fully relaxed. The activation energy barrier for $\mathrm{O} 2$ diffusion from $\mathrm{h}-\mathrm{BN}$ to graphene found to be as low as $0.05 \mathrm{eV}$. The barriers for the rest of the considered path are also quite low. The adsorption energies is are listed in table 1. The best simulation was found for 5; 5; 3 mole ratio of $\mathrm{H}_{2}, \mathrm{O}_{2}$ and $\mathrm{C}_{2} \mathrm{~F}_{4}$ (Table 1 ).

Table l: The adsorption of $\mathrm{H} 2$ and $\mathrm{N} 2$ on surface of graphene

\begin{tabular}{|l|l|l|}
\hline No. $\mathrm{H}_{2}$ & \multicolumn{1}{|c|}{$E_{\text {adsorb }}^{\mathrm{H} 2}$} & \multicolumn{1}{c|}{$E_{\text {adsorb }}^{\text {O2 }}$} \\
& $e V / \mathrm{H}_{2}$ & $e V / \mathrm{O}_{2}$ \\
\hline $1 \mathrm{H}_{2}$ & -0.65 & -0.36 \\
\hline $2 \mathrm{H}_{2}$ & -0.58 & -0.38 \\
\hline $3 \mathrm{H}_{2}$ & -0.54 & -0.44 \\
\hline $4 \mathrm{H}_{2}$ & -0.61 & -0.39 \\
\hline $5 \mathrm{H}_{2}$ & -0.69 & -0.48 \\
\hline $6 \mathrm{H}_{2}$ & -0.57 & -0.41 \\
\hline $7 \mathrm{H}_{2}$ & -0.55 & -0.43 \\
\hline $8 \mathrm{H}_{2}$ & -0.51 & -0.46 \\
\hline $9 \mathrm{H}_{2}$ & -0.54 & -0.42 \\
\hline $10 \mathrm{H}_{2}$ & -0.56 & -0.39 \\
\hline
\end{tabular}

For any further adsorption model, the validation of the Langmuir-Freundlich multilayer isotherm model is done by using breakthrough experiments with binary mixtures of $\mathrm{H}_{2} / \mathrm{O}_{2}, \mathrm{O}_{2} / \mathrm{N}_{2}$ and $\mathrm{H}_{2} / \mathrm{H}_{2} \mathrm{O}$ (steam) and, a few component mixture composed by $\mathrm{H}_{2} / \mathrm{O}_{2} / \mathrm{H}_{2} \mathrm{O} / \mathrm{N}_{2}$. Breakthrough simulations are performed for different pressures, flow rates and different number molecules of adsorbent and also different sheets including graphite and $\mathrm{h}-\mathrm{BN}$. The results are then compared with experimental data from the 
REVISTA DE LA UNIVERSIDAD DEL ZULIA. 3época. Año 11 N²9, 2020 A. Chitsazan et al./// Increased efficiency of a fuel cell using h-BN electrodes... 60-78

literature. The Multisite Langmuir multilayer isotherm model and simulations with a four component mixtures of $\mathrm{H}_{2} / \mathrm{O}_{2} / \mathrm{H}_{2} \mathrm{O} / \mathrm{N}_{2}$ and are listed in table 2 .

Table 2. Langmuir multilayer isotherm model of $\mathrm{H}_{2} / \mathrm{O}_{2} / \mathrm{H}_{2} \mathrm{O} / \mathrm{N}_{2}$

\begin{tabular}{|l|l|l|l|l|}
\hline Gas & $\begin{array}{l}\mathrm{K}_{1} \\
\text { Mol.Kg-1.K-1 }\end{array}$ & $\begin{array}{l}\mathrm{K}_{2} \\
\text { Mol.Kg-1. } \\
\mathrm{K}^{-1} \mathrm{~T}^{-1}\end{array}$ & $\begin{array}{l}\mathrm{K}_{3} \\
\text { atm-1 }\end{array}$ & $\begin{array}{l}\mathrm{k} \\
\mathrm{K}\end{array}$ \\
\hline \multicolumn{5}{|c|}{ Graphene } \\
\hline $\mathrm{H}_{2}$ & 16.9 & $-2^{*} 10^{2}$ & $0.6^{*} 10^{4}$ & 1200 \\
\hline $\mathrm{N}_{2}$ & 1.7 & $-0.8^{*} 10^{2}$ & $5^{*} 10^{6}$ & 320 \\
\hline $\mathrm{O}_{2}$ & 30.1 & $-9.0^{*} 10^{2}$ & $2.1^{*} 10^{4}$ & -650 \\
\hline $\mathrm{H}_{2} \mathrm{O}$ & 27.5 & $-7.0^{*} 10^{2}$ & $9^{*} 10^{5}$ & 1002 \\
\hline & \multicolumn{1}{|c|}{$\mathrm{h}-\mathrm{BN}$} \\
\hline $\mathrm{H}_{2}$ & 1.3 & $-1.5^{*} 10^{2}$ & $25.1^{*} 10^{4}$ & 450 \\
\hline $\mathrm{N}_{2}$ & 4.8 & $-0.65^{*} 10^{2}$ & $5.6^{*} 10^{4}$ & 1530 \\
\hline $\mathrm{O}_{2}$ & 11.8 & $-3.1^{*} 10^{2}$ & $199^{*} 10^{4}$ & 730 \\
\hline $\mathrm{H}_{2} \mathrm{O}$ & 10.3 & $-1.8^{*} 10^{2}$ & $1.6^{*} 10^{4}$ & 209 \\
\hline
\end{tabular}


REVISTA DE LA UNIVERSIDAD DEL ZULIA. 3épeca. Año 11 N $^{\circ}$ 29, 2020 A. Chitsazan et al./// Increased efficiency of a fuel cell using h-BN electrodes... 60-78
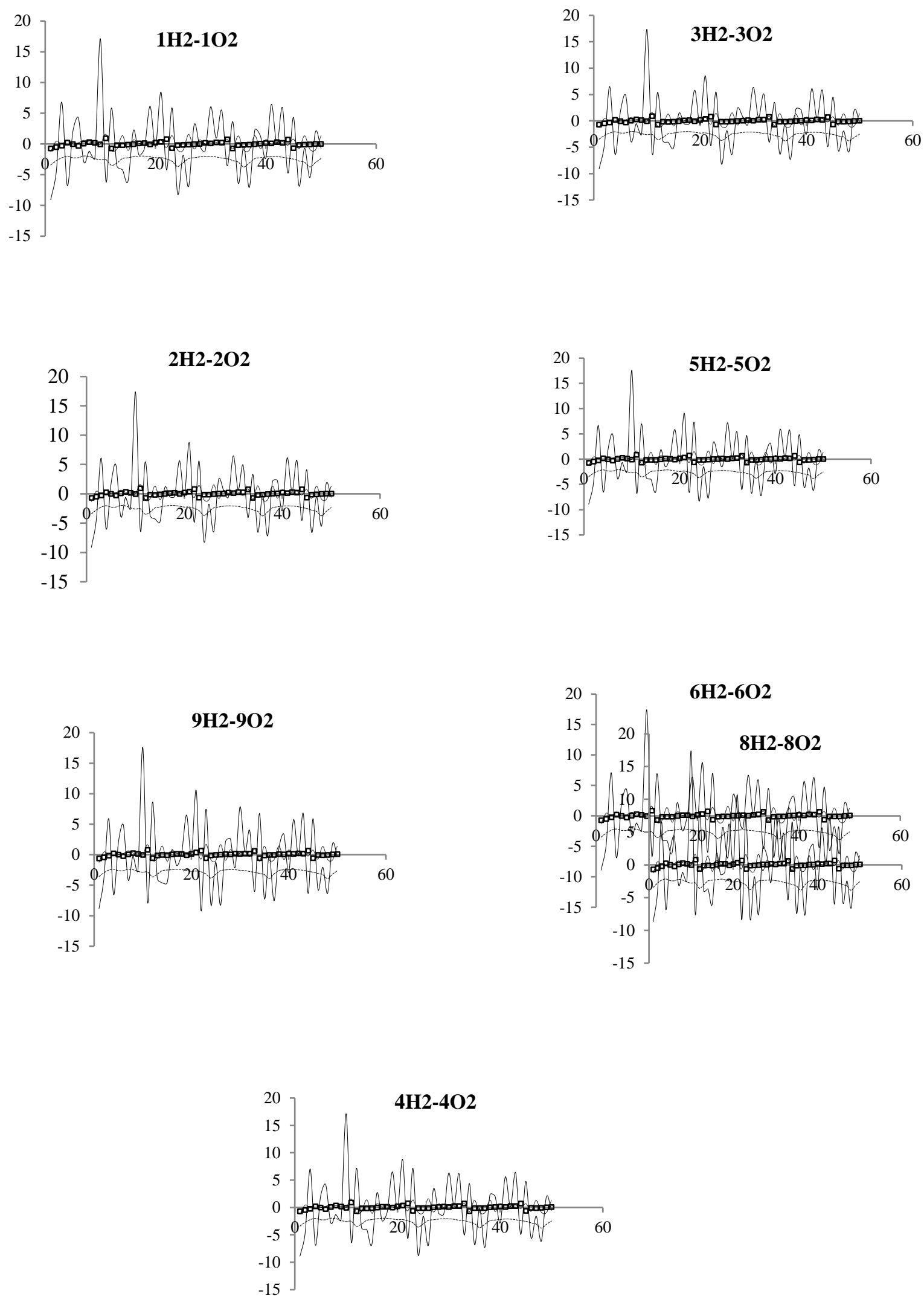
REVISTA DE LA UNIVERSIDAD DEL ZULIA. 3época. Año 11 N 29, 2020

A. Chitsazan et al. /// Increased efficiency of a fuel cell using h-BN electrodes... 60-78
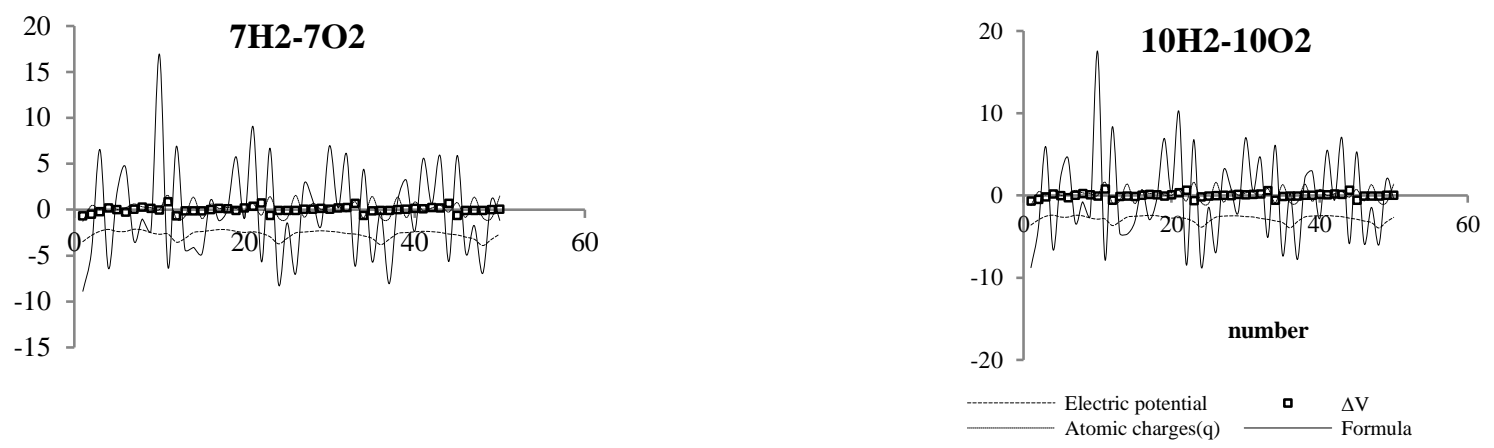

Fig.3 Electrical potential and Difference voltages of 10 situations of $\mathrm{H} 2$ and $\mathrm{O} 2$ adsorption versus distance

\section{References}

Besler, B.H., Merz, K.M., Kollman, P.A. (1990). Atomic charges derived from semi empirical methods J. comp. Chem (11): 431-439, DOI: 10.1002/jcc.540110404

Borup R. (2007). Scientific aspects of polymer electrolyte fuel cell durability and degradation. CHEMICAL REVIEWS, 107(10), 3904-3951.

Bosco , A .D. P., Fronk, M .H. (2000). Fuel cell flooding detection and correction, US Patent 6,103,409.

Chirlian, L.E., Francl, M.M. (1987). Atomic charges derived from electrostatic potentials: A detailed study. J.comp.chem (8): 894-905, DOI: 10.1002/jcc.540080616

Ciureanu, M., (2004). Effects of nafion dehydration in pem fuel cells. Journal of Applied Electrochemistry, 34(7):705-714

Cruz-Manzo, S., Chen, R., Rama P. (2013). Study of current distribution and oxygen diffusion in the fuel cell cathode catalyst layer through electrochemical impedance spectroscopy. International Journal of Hydrogen Energy, 38(3), 1702- 1713

De Bruijn, FA., Dam, VAT., (2008). Janssen GJM. Review: Durability and degradation issues of PEM fuel cell components. Fuel Cells, 8(3), 22

Dutta, S., Shimpalee, S., Van, Zee J W. (2000). Three-dimensional numerical simulation of straight channel pem fuel cells. Journal of Applied Electrochemistry, 2000, 30(2):135-146 
REVISTA DE LA UNIVERSIDAD DEL ZULIA. 3época. Año 11 N²9, 2020 A. Chitsazan et al./// Increased efficiency of a fuel cell using h-BN electrodes... 60-78

Futerko, P., Hsing, I., (2000). Two-dimensional finite-element method study of the resistance of membranes in polymer electrolyte fuel cells, Electrochimica Acta, 45(11):17411751

Gurau V. (1998). Two-dimensional model for proton exchange membrane fuel cells. AIChE Journal, 44(11):2410- 2422

Karimi, G. (2011). Along-channel flooding prediction of polymer electrolyte membrane fuel cells. International Journal of Energy Research, 35(10):883-896

Kazmi, I. H., Bhatti, A. I., Iqbal, S. A. (2009). nonlinear observer for pem fuel cell system.Multitopic Conference, IEEE 13th International, pages 1-6

Larminie, J., Dicks, A. (2003). Fuel Cell Systems Explained. J. Wiley

Le, Canut J., Abouatallah, R. M., Harrington, D. A., (2006). Detection of membrane drying, fuel cell flooding, and anode catalyst poisoning on pemfc stacks by electrochemical impedance spectroscopy, 153(5): 857-864

Litster, S., McLean, G. (2004). PEM fuel cell electrodes. Journal of Power Sources, $130(1): 61,76$

Mollaamin, F. , Pham, T., Dang, D., Monajjemi, M., Mau Dang, C. (2019). Modelling and Controlling of ion transport rate efficiency in Proton exchange membrane (PEMFC), alkaline (AFC), direct methanol (DMFC), phosphoric acid (PAFC), direct forming acid (DFAFC) and direct carbon (DCFC) fuel cells, Biointerface Research in Applied Chemistry, 9 (4), $2019,4050-4059$.

Pasaogullari, U., Wang, C. (2005). Two-phase modeling and flooding prediction of polymer electrolyte fuel cells. Journal of The Electrochemical Society, 152(2): 380-390

Perdew, J. P, Burke, K. (1996). Ernzerhof, Generalized Gradient Approximation Made Simple. Phys. Rev. Lett, (77): 3865-3868

Pukrushpan, J .T., Peng, H., Stefanopoulou, A .G. (2004). Control-oriented modeling and analysis for automotive fuel cell systems. Journal of Dynamic Systems, Measurement, and Control, 126:14

Rowe, A., Li, X. (2001). Mathematical modeling of proton exchange membrane fuel cells, Journal of Power Sources, 102(1):82-96

Schmidt, M.W., Baldridge, k.k., Boatz, J.A., Elbert, S.T., Gordon, Ms., Jensen, JH., Koseki, S., Matsunaga, N., Nguyen, K.A et al. (2004). General atomic and molecular electronic structure system. J Compt chem, 14(11): 1347-1363 
REVISTA DE LA UNIVERSIDAD DEL ZULIA. 3época. Año 11 N²9, 2020 A. Chitsazan et al./// Increased efficiency of a fuel cell using h-BN electrodes... 60-78

Schmittinger, W., Vahidi, A., (2008). A review of the main parameters influencing longterm performance and durability of PEM fuel cells. Journal of Power Sources, 180(1):114

Siegel, C. (2008). Review of computational heat and mass transfer modeling in polymerelectrolyte-membrane (pem) fuel cells. Energy, 33(9):1331-1352

Tao, W. Q., Min, C. H., Liu, X. L., He, L. Y., Yin, B. H., Jiang, W. (2006). Parameter sensitivity examination and discussion of PEM fuel cell simulation model validation: Part i. current status of modeling research and model development. Journal of Power Sources, 160(1):359-373

Wang, Z. H., Wang, C .Y., Chen, K. S., (2001). Two-phase flow and transport in the air cathode of proton exchange membrane fuel cells. Journal of Power Sources, 94(1):40- 50

Yao, K. Z., Karan, K., McAuley, K. B., Oosthuizen, P., Peppley, B., Xie, T., (2004). A review of mathematical models for hydrogen and direct methanol polymer electrolyte membrane fuel cells. Fuel Cells, 4(1), 3-29

Zawodzinski, T .A, Derouin ,C., Radzinski, S., Sherman, R. J., Smith, V. T., Springer, T. E., Gottesfeld ,S.' (1993). Water uptake by and transport through nafion membranes, 140(4):1041-1047.

Zhao, Y., Truhlar, DG. (2008). The M06 suite of density functional for main group thermochemistry, thermochemical kinetics, non-covalent interactions, excited states, and transition elements: two new functional and systematic testing of four M06-class functional and 12 other functional. Theor Chem Account 2008; 120:215-241 